\title{
PENENTUAN BESARAN NAFKAH MADHIYAH, NAFKAH IDDAH DAN MUT'AH DALAM PERKARA PERCERAIAN DI PENGADILAN AGAMA
}

\author{
Riyan Ramdani ${ }^{1 *}$, Firda Nisa Syafithri ${ }^{2}$ \\ ${ }^{1}$ UIN Sunan Gunung Djati Bandung, Indonesia \\ ${ }^{2}$ UIN Sunan Gunung Djati Bandung, Indonesia \\ *Correspondence: riyanramdani@uinsgd.ac.id
}

Recived: 28 Februari 2021; Accepted: 30 Maret 2021; Published: 31 Maret 2021

\begin{abstract}
In navigating the household ark, disharmony cannot be avoided, one of which is the result of neglecting rights and obligations that lead to the breakdown of a marriage. One of the consequences is the burden on the husband to pay for the maintenance of madhiyah, iddah, and mut'ah. A wife has the right to request payment of maintenance to the Religious Court if the husband does not fulfill his obligation to provide for his services. This study aims to explain the legal basis and considerations of the panel of judges in determining the levels of the amount of madhiyah, iddah, and mut'ah livelihoods. This study uses normative juridical research to examine statutory regulations related to determining the amount of madhiyah, iddah, and mut'ah livelihoods. The results showed that First. Determination of the amount of income for the former husband is adjusted according to the ability of the husband as stated in Presidential Instruction No. 1 of 1991 concerning KHI, Law no. 1 of 1974, and SEMA No. 3 of 2018 Results of the Plenary of Religion point 2 as the refinement of SEMA No. 7 of 2012 number 16 and Article 149 letter b of the KHI. In the case of divorce talak. (Article 8 number (3) letter (c) PERMA No. 3 of 2017) the maintenance of mut'ah and iddah is paid together with the pledge of divorce when pronounced by the Petitioner. Second, the judges' consideration of determining the level of the amount of living is based on a) the wife does not commit nusyur, b) the husband's economic condition, c) the consideration of the reasonable needs of each party.
\end{abstract}

Keywords: divorce, alimony Madhiyah, Iddah, Mut'ah.

\begin{abstract}
Abstrak
Dalam mengarungi bahtera rumah tangga tentunya tidak dapat dihindari adanya ketidakharmonisan, yang salah satunya diakibatkan dari terbengkalainya hak dan kewajiban yang menyebabkan putusnya perkawinan. Salah satu akibatnya ialah berupa pembebanan terhadap suami untuk membayar nafkah madhiyah, iddah dan mut'ah. Seorang istri berhak memohon pembayaran nafkah kepada Pengadilan Agama jika suami sudah tidak memenuhi kewajibannya menafkahi. Penelitian ini bertujuan untuk menjelaskan dasar hukum dan pertimbangan majelis hakim dalam
\end{abstract}


menentukan kadar besaran nafkah madbijah, iddah dan mutah. Penelitian ini menggunakan penelitian yuridis normatif untuk mengkaji peraturan perundangundangan berhubungan dengan penentuan besaran nafkah madbiyah, iddah dan mut'ah. Hasil penelitian menunjukan bahwa Pertama. Penentuan besaran nafkah terhadap bekas suami disesuaikan sesuai kemampuan suami sebagimana Inpres No. 1 Tahun 1991 tentang KHI, UU No. 1 Tahun 1974, dan SEMA No. 3 Tahun 2018 Hasil Pleno Agama poin 2 sebagai penyempuranaan SEMA No. 7 Tahun 2012 angka 16 dan Pasal 149 huruf b KHI. Dalam perkara cerai talak (Pasal 8 angka (3) huruf (c) PERMA No. 3 tahun 2017) nafkah mut'ah dan iddah di bayarkan bersamaan ikrar talak ketika di ucapkan oleh Pemohon. Kedua, Pertimbangan majelis hakim terhadap penentuan kadar besaran nafkah didasarkan: a) istri tidak melakukan perbuatan nusyur, b) kondisi ekonomi suami, c) pertimbangan kebutuhan yang wajar dari masing-masing pihak.

Kata Kunci: perceraian; nafkah Madhiyah; Iddah; Mut'ah.

\section{Pendahuluan}

Dalam membentuk keluarga yang harmonis, damai dan tentram. Nafkah tentunya memiliki fungsi dan pengaruh sangat besar untuk keberlangsungan suatu rumah tangga. Apabila nafkah tersebut tidak dapat terpenuhi atau kurang mencukupi, dapat manimbulkan permasalahan rumah tangga yang dapat berujung berakhirnya rumah tangga (perceraian). ${ }^{1}$

Ketika terjadinya perceraian antara suami dan istri maka tentunya akan timbul beberapa hak dan kewajiban yang harus ditunaikan oleh masing-masing pihak. Terhadap mantan suami kewajiban yang harus dilaksanakan ialah salah satunya memberi nafkah madiyah (nafkah lampau) sebagai salahsatu kewajiban dalam bentuk ketentuan hukum akibat putusnya perkawinan karena perceraian, adanya pemberian nafkah iddah dan nafkah mut'ah kepada mantan istri serta kepada anaknya yang belum mumayyiz yang dalam pengasuhan ibunya (hak badhanah).

Untuk besarannya tidak ada pengaturan secara jelas dan terperinci tentang kadar nafkah yang dapat diberikan oleh mantan suami, namun perlu ada dasar hukum yang dipergunakan oleh hakim dalam menetapkan suatu putusan yang menjadi dasar pertimbangan oleh majelis hakim. Pembahasan terkait kewajiban mantan suami setelah jatuhnya cerai, dibahas secara lengkap dalam kajian fikih hukum keluarga (abwal syakhsiyyah) dalam buku-buku fikih Islam. ${ }^{2}$ Selain itu

1 Jumni Nelli, "Analisis Tentang Kewajiban Nafkah Keluarga Dalam Pemberlakuan Harta Bersama," Al-Istinbath: Jurnal Hukum Islam 2, no. 1 (2017): hlm. 36, https://doi.org/10.29240/jhi.v2i1.195.

2 Nandang Ihwanudin, "Pemenuhan Kewajiban Pasca Perceraian Di Pengadilan Agama," ADLIYA: Jurnal Hukum Dan Kemanusiaan 10, no. 1 (2019): hlm. 52, https://doi.org/10.15575/adliya.v10i1.5146. 
objek kajian fikih tersebut diantaranya membahas juga mengenai nafkah iddah, mut'ah dan nafkah anak.

Permasalahan berkenaan dengan penentuan besaran nafkah atau kebutuhan keluarga telah diatur dalam al-Quran, sunnah, dan ijma ${ }^{33}$ serta dalam hukum positif di diatur dalam peraturan perundang-undangan yang berlaku di Indonesia, nafkah tersebut merupakan kewajiban yang harus dipenuhi oleh suami. Sebagaimana dituangkan dalam Pasal 34 Ayat (1) Undang-Undang No. 1 Tahun 1974 tentang Perkawinan dan Pasal 80 Ayat (4) Kompilasi Hukum Islam. Pasal 34 Ayat (1) Undang-Undang Perkawinan menyebutkan bahwa Suami wajib melindungi isterinya dan memberikan segala sesuatu keperluan hidup berumah tangga sesuai dengan kemampuannya.

Sulaiman Rasjid menyebutkan bahwa nafkah adalah segala keperluan yang timbul berdasarkan keadaan serta tempat, baik itu pakaian ataupun rumah. Adapun terkait penentuan besaran nafkah, dapat disesuaikan berdasarkan keadaan maupun kesanggupan orang yang memiliki kewajiban tersebut bertolak dari kebiasaan masing-masing dan hanya sekedar untuk mencukupi keperluan serta kebutuhan. ${ }^{4}$ Ungkapan tersebut didasarkan kepada suatu riwayat berkaitan dengan keadaan istri Abu Sufyan sebagaimana dijelaskan dalam hadits berikut: "Hendaklah orang yang mampu memberi nafkah menurut kemampuan-nya." (Ath-Talaq: 7).

Kompilasi Hukum Islam (KHI) telah mengatur berkaitan dengan nafkah sebagaimana dijelaskan pada Pasal 80 ayat 4 “...(4) Sesuai dengan pengahasilannya suami menanggung: a) nafkah, kiswah, dan tempat kediaman bagi istri; b) biaya rumah tangga, biaya perawatan dan biaya pengobatan bagi istri dan anak; c) biaya pendidikan bagi anak".

Aulia Muthiah menjelaskan bahwa kewajiban nafkah didasarkan atas kemampuan dari pihak suami, sehingga dalam hal nafkah ini istri hendaklah berlaku wajar serta tak berlebihan dalam meminta hak nya berupa tempat tinggal, makanan, minuman dan pakaian. ${ }^{5}$ Kewajiban memberikan nafkah timbul sebagai akibat hukum dari adanya perkawinan. Maka dapat dikatakan bahwa nafkah menjadi bagian yang tidak terpisahkan dari perkawinan.

Ketika terjadi perselisihan dalam suatu rumah tangga yang mengarah kepada berpisahnya suami dan istri (perceraian), maka penyelesaian perselisihan tersebut menjadi salah satu salah satu perkara yang menjadi kewenangan absolut dari Pengadilan Agama, hal ini sebagaimana Pasal 49 UU No. 7 Tahun 1989

3 Hasanatul Jannah, "Kompetensi Hukum Pemenuhan Nafkah Istri Pasca Perceraian," De Jure, Jurnal Syariah Dan Hukum 2, no. 1 (2010): hlm. 79, https://doi.org/https://doi.org/10.18860/j-fsh.v2i1.57.

4 H. Sulaiman Rasjid, Fiqh Sunnah (Bandung: Sinar Baru Algesindo, 1994).

5 Aulia Muthi'ah, Hukum Islam Dinamika Seputar Hukum Keluarga (Yogjakarta: Pustaka Baru, 2017). 
sebagaimana diubah Undang-Undang Nomor 3 Tahun $2006^{6}$ "Pengadilan Agama bertugas dan berwenang memeriksa, memutus, dan menyelesaikan perkara-perkara di tingkat pertama antara orang-orang yang beragama Islam di bidang: a. Perkawinan; b. Kewarisan, wasiat dan hibah, yang dilakukan berdasarkan hukum islam; c. Wakaf dan shadaqah.”

Cik Hasan Bisri menjelaskan bahwa pengadilan sebagai penyelenggara peradilan, yaitu organisasi yang di dalamnya ditegakkan hukum serta keadilan. Berhubung peradilan merupakan organisasi, maka di dalamnya terdapat susunan ataupun struktur organisasi. ${ }^{7}$ Setiap perkara yang berhubungan dengan keluarga (ahwal syakbsiyyah) baik itu hubungan suami istri, mahar (maskawin), nikah, talaq, rujuk, li'an, al walad, hadhanah, wasiat, waris serta nafkah merupakan kewenangan Pengadilan. ${ }^{8}$

Di Indonesia sendiri perceraian diklasifikasikan menjadi dua macam berdasarkan pihak yang mengajukan, yaitu cerai gugat jika yang mengajukan dari pihak istri, sedangkan jika yang mengajukannya adalah pihak suami maka disebut cerai talak. Perceraian dibedakan oleh Undang-undang berdasarkan kehendak istri dan perceraian berdasarkan kehendak suami, hal ini disebabkan karakteristik yang berbeda dari hukum Islam, sehingga proses perceraian berdasarkan kehendak istri akan berbeda dengan proses perceraian berdasarkan kehendak suami. ${ }^{9}$

Pertama, Cerai Talak ditegaskan dalam Pasal 114 KHI. "Putusnya perkawinan yang disebabkan karena perceraian dapat terjadi karena talak atau berdasarkan gugatan perceraian". Penjelasan lebih lanjut pada Pasal 129 KHI. "Seorang suami yang akan menjatuhkan talak kepada istrinya mengajukan permohonan baik lisan maupun tertulis kepada Pengadilan Agama yang mewilayahi tempat tinggal istri dengan alasan serta meminta agar diadakan sidang untuk keperluan itu."

Kedua, Cerai Gugat ditegaskan dalam Pasal 132 ayat 2. "Gugatan perceraian diajukan oleh isteri atau kuasanya pada Pengadilan Agama yang daerah hukumnya mewilayahi tempat tinggal Penggugat kecuali istri meninggalkan tempat kediaman tanpa izin suami."

Adanya perbedaan dalam pengajuan antara cerai gugat dan cerai talak kepada Pengadilan Agama, menunjukkan bahwa masing-masing perkara memiliki konsekuensinya tersendiri. Hal mendasar yang kemudian harus dipahami terkait

6 Fatmawati Fatmawati, "Kewenangan Peradilan Agama Dalam Memutus Perkara Perceraian Akibat Murtad," Jurnal Ilmiah Pendidikan Pancasila Dan Kewarganegaraan 2, no. 1 (2017): hlm. 27, https://doi.org/10.17977/um019v2i12017p026.

7 Cik Hasan Bisri, Peradilan Islam Dalam Tatanan Masyarakat Indonesia (Bandung: Rosdakarya, 1997).

8 Oyo Sunaryo Mukhlas, Perkembangan Peradilan Islam (Bandung: Ghalia Indonesia, 2011).

9 Sheila Fakhria, "Cerai Gugat Dan Implikasinya Terhadap Hak-Hak Finansial Perempuan," Legitima: Jurnal Hukum Keluarga Islam 1, no. 1 (2019): Hlm. 101, https://doi.org/10.33367/legitima.v1i1.648. 
konsekuensi terhadap cerai talak sebagaimana Pasal 41 huruf c dalam UU No. 1 Tahun 1974 menyebutkan: “(c) Pengadilan dapat mewajibkan kepada bekas suami untuk memberikan biaya penghidupan dan/atau menentukan sesuatu kewajiban bagi bekas isteri."

Serta dijelaskan pula pada Pasal 149 Kompilasi Hukum Islam yang berbunyi: "Bilamana perkawinan putus karena cerai talak maka bekas suami wajib: a) memberikan mut'ah yang layak kepada bekas isterinya, baik berupa uang atau benda, kecuali bekas isteri tersebut qobla al dukbul; b) memberi nafkah, maskan dan kiswah kepada bekas isteri selama dalam iddah, kecuali bekas isteri telah di jatuhi talak ba'in atau nusyuz dan dalam keadaan tidak hamil; c) melunasi mahar yang masih terhutang seluruhnya, dan separoh apabila qobla al dukbul; d) memeberikan biaya hadhanan untuk anak-anaknya yang belum mencapai umur 21 tahun.”

Disamping itu, terhadap perkara cerai talak yang diajukan oleh Suami terhadap istrinya maka sebagaimana ditegaskan dalam Pasal 140 KHI bahwa, bekas suami diharuskan memenuhi kebutuhan rumah tangga yakni berupa nafkah, baik nafkah mut'ah, nafkah madhiyah maupun nafkah iddah dan nafkah anak. Kendati demikian, penentuan besaran nafkah untuk perkara cerai talak sampai saat ini belum diatur dalam suatu aturan perundang-undangan sebagaimana SEMA No. 3 Tahun 2018 Hasil Pleno Kamar Agama.

Penelitian yang dilakukan oleh Ummu Kalsum ${ }^{10}$ tentang pertimbangan Hakim terhadap nafkah istri dalam kasus cerai talak di Pengadilan Agama Watampone Kelas 1A menjelaskan bahwa pemberian nafkah dapat diberikan sebelum atau sesudah ikrar talak, akan tetapi dalam prakteknya di Pengadilan Agama Watampoe pemberian tersebut diberikan sebelum ikrar talak, karena demi mencapai nilai-nilai keadilan, kemanfaatan dan kepastian hukum. Pembebanan nafkah tersebut ditujukan untuk menghindari kemungkinan terjadinya kemadharatan setelah terjadinya perceraian.

Berdasarkan penjelasan diatas, penelitian mencoba untuk menjelaskan dasar hukum serta pertimbangan majelis hakim dalam menentukan besaran nafkah madhiyah, nafkah iddah dan mut'ah yang terjadi dalam perkara perceraian yang diatur dalam peraturan perundang-undangan.

\section{Metodologi}

Penelitian ini menggunakan metode yuridis normatif (legal research) dengan mengambil data-data yang dibutuhkan melalui sumber-sumber kepustakaan yang berhubungan dengan fokus penelitian, baik itu bersumber dari UU No. 1 Tahun 1974 tentang Perkawinan maupun dari Inpres No. 1 Tahun 1991 tentang

10 Ummu Kalsum, "Pertimbangan Hakim Terhadap Nafkah Istri Dalam Kasus Cerai Talak Di Pengadilan Agama Watampone Kelas 1 A," Jurisprudentie: Jurusan Ilmu Hukum Fakultas Syariah Dan Hukum 6, no. 2 (2019): hlm. 248, https://doi.org/10.24252/jurisprudentie.v6i2.9766. 
Kompilasi hukum Islam serta Surat Edaran Mahkamah Agung yang dalam hal ini SEMA Nomor 3 Tahun 2018. Metode analisis dalam penelitian ini menggunakan content analysis, penelitan yang bersifat normatif yang bersumber dari penafsiran teks suatu dokumen ataupun bahan bacaan lainnya yang mengandung permasalahan untuk kemudian dijadikan sebagai penelitian. Cik Hasan Bisri menjelaskan metode content analysis dirumuskan dari kesimpulan tiap teks bacaan yang terdapat pada media massa maupun surat kabar. Maka dari itu, content analysis yakni metode yang dipakai dalam penelitian yang bersifat kuantitatif, namun dapat juga diadaptasi pada penelitian kualitatif. Analisis terhadap putusan pengadilan atau yurisprudensi dan lembaga yudikatif lainnya dapat menggunakan metode ini.

Teknik pengumpulan data pada penelitian ini adalah melalui metode studi kepustakaan yakni teknik dengan dilakukannya pengolahan data yang bersumber dari berbagai literatur maupun sumber bahan bacaan buku ataupun jurnal dengan tujuan untuk mengetahui landasan teoritis dalam sebuah penelitian. Dalam mengambil permasalahan berkenaan dengan penentuan besaran nafkah madhiyah, nafkah iddah maupun mut'ah dalam sebuah perkara perceraian. Kebenaran suatu hasil penelitan dapat diperkuat dengan dilakukannya studi kepustakaan, yakni dengan menelaah konsep-konsep yang berhubungan dengan masalah penelitian. Hal tersebut selaras dengan penjelasan Winaro Surachmad bahwa penelitian tidak akan mencapai titik kesempurnaan jika tidak ditunjang dengan kepustakaan. ${ }^{11}$

\section{Hasil Penelitian dan Pembahasan}

Pada dasarnya kewajiban seorang suami dalam memberikan nafkah untuk memenuhi kebutuhan keluarga perundang-undangan di Indonesia diatur dalam pengaturan tentang penyebarluasan Kompilasi Hukum Islam diatur dalam Inpres No. 1 Tahun 1991. Selain pengaturan tentang nafkah, dalam KHI pun dijelaskan pula pengaturan tentang harta kekayaan perkawinan yang juga erat kaitannya dengan kewajiban suami dalam memenuhi nafkah. Pada dasarnya, telah disebutkan dalam KHI bahwa perkawinan tidak menjadikan harta suami dan istri bercampur.

Maka dari itu, harta yang dibawa oleh istri tetap menjadi hak istri dan dikuasai sepenuhnya oleh istri. Begitupun sebaliknya, harta yang dibawa oleh suami tetap menjadi hak suami dan dikuasai sepenuhnya oleh suami. Hal teserbut selaras dengan konsep yang tercantum dalam UU No. 1 Tahun 1974 tentang Perkawinan serta KUHPerdata. Di sisi lain, Al-Qur'an maupun Hadits tidak menjelaskan bahwasanya selama perkawinan berlangsung, seluruh harta yang diperoleh suami adalah sepenuhnya menjadi hak suami, sedangkan isteri hanya terbatas atas nafkah yang diberikan suami. ${ }^{12}$

11 A Arnengsih and Mohamad Sar'an, "Hak Asuh Anak Akibat Cerai Gugat Dalam Perkara Nomor 0915/Pdft.G/2017/PA.Bgr," Al-Ahwal Al-Syakbsiyyab: Jurnal Hukum Keluarga Dan Peradilan Islam 1, no. 2 (2020): hlm. 18, https://doi.org/10.15575/as.v1i2.9910.

12 Nelli, "Analisis Tentang Kewajiban Nafkah Keluarga Dalam Pemberlakuan Harta Bersama," hlm. 30 . 
Mempertahankan ikatan perkawinan kerap sekali menjadi sebuah tantangan tersendiri dalam rumah tangga, tidak sedikit yang terguncang di tengah jalan diakibatkan pelbagai macam ancaman yang dapat menghancurkan ikatan perkawinan suami istri. Ikatan perkawinan akan beresiko menjadi rapuh hingga akhirnya berakhir dengan perceraian. ${ }^{13}$ Perceraian merupakan usainya sebuah ikatan perkawinan yang disebabkan hal-hal tertentu. Perceraian berdasarkan keputusan hakim yang dicatat pada catatan sipil ataupun berlandaskan UU No. 1 Tahun 1974 tentang Perkawinan. Pengadilan Agama akan mengabulkan gugatan perceraian apabila telah terbukti adanya alasan-alasan yang dapat dibenarkan oleh hukum maupun pertimbangan hakim bahwa ikatan suami istri sudah tidak mungkin melanjutkan hubungan rumah tangga bersama. ${ }^{14}$

\section{Penentuan Kadar Besaran Nafkah Madhiyah, Iddah dan Mut'ah}

Memberi nafkah merupakan salah satu kewajiban yang pasti berdasarkan hukum Islam, hal ini sebagaimana desebutkan dalam Surat Al-Baqarah: 233 yang menyebutkan bahwa "Kewajiban ayah (suami) untuk memberi makan dan pakaian kepada para ibu (istri) dengan cara ma'ruf atau baik dan patut. Seseorang (suami) tidak dibebani melainkan menurut kadar kesanggupannya".

Dasar hukum lain tentang nafkah juga tercantum dalam surah Ath-Thalaq ayat 7 "Hendaklah orang yang mampu memberi nafkah menurut kemampuannya. Dan orang yang disempitkan rezekinya hendaklah memberi nafkah dari harta yang diberikan Allah kepadanya. Allah tidak memikulkan beban kepada seseorang melainkan (sekedar) apa yang Allah berikan kepadanya. Allah kelak akan memberikan kelapangan sesudah kesempitan."

Dalam hukum positif tentunya diatur dalam berbagai aturan perundangundangan, diantaranya dalam Ketentuan Pasal 41 huruf c dalam UU No. 1 Tahun 1974 yang menyebutkan bahwa: “(c) Pengadilan dapat mewajibkan kepada bekas suami untuk memberikan biaya penghidupan dan/atau menentukan sesuatu kewajiban bagi bekas isteri."

Kewajiban yang harus ditunaikan oleh pihak suami yang harus dipenuhi terhadap mantan istri dan anaknya adalah sebagai berikut: Pertama, Nafkah madbiyah adalah nafkah yang telah lampau tidak selalu dihubungkan dengan perkara cerai talak, yang kemudian dalam hal ini istri dapat mengajukan tuntutan nafkah madiyah saat suaminya mengajukan perkara cerai talak dengan mengajukan gugatan rekonvensi. Kedua, Nafkah iddah sebagai dasar pemikiran bahwa pada perkara cerai

13 Ramdani Wahyu Sururie and Harry Yuniardi, "Perceraian Dalam Keluarga Muslim Di Jawa Barat,” Jurnal Al-Manahij XII, no. 2 (2018): hlm. 264, https://doi.org/https://doi.org/10.24090/mnh.v12i2.1361.

14 Gozwan Jundan, "Perceraian Usia Tiga Tahun Perkawinan Dari Pasangan Muda," Al-Abwal Al-Syakhsiyyah: Jurnal Hukum Keluarga Dan Peradilan Islam 1, no. 1 (2020): hlm. 41, https://doi.org/10.15575/as.v1i1.7801. 
gugat adalah terjadinya fakta bahwa pasca putusan, mantan isteri menjalani massa iddah. Sehingga konsep nafkah iddah sebagaimana dijelaskan dalam Al-Qur'an dijadikan illat yang sama terhadap perkara cerai talak. Nafkah iddah itu sendiri merupakan pendapatan suami yang wajib diberikan kepada istri untuk memenuhi kebutuhan pokok selama masa tunggu sampai habis masa iddahnya. ${ }^{15}$ Ketiga, Nafkah mut'ah Mut'ah adalah bentuk pakaian berupa atau harta oleh suami yang diberikan kepada istri yang dia ceraikan untuk menghibur hati istri, dan untuk menghapus rasa penderitaan dari istri akibat adanya perpisahan. ${ }^{16}$ Nafkah nut'ab diberikan dengan tujuan meminimalisir rasa sedih dan atau penderitaan yang dialami oleh istri yang telah diceraikan bekas suaminya. Maka diwajibkanlah bagi mantan suami untuk memberikan nafkah mut'ah sebagai penghilang pilu. Namun beberapa pendapat menyatakan bahwa apabila yang mengajukan adalah istri yakni dalam perkara cerai gugat, maka nafkah mut ${ }^{e e}$ h dianggap tidak ada. Dengan melihat tidak adanya derita yang dialami oleh istri. Keempat, Nafkah anak yakni nafkah yang diberikan untuk keperluan anak, nafkah ini tentunya diberikan setelah terjadinya perceraian. Dimana hal terseubt tidak menutup kemungkinan dibolehkan dalam perkara cerai gugat untuk mengajukan tuntutan atas nafkah anak.

Seperti diketahui dalam Pasal 80 ayat (4) huruf a memberikan penjelasan bahwa sesuai dengan penghasilannya suami menanggung nafkah, pasal ini menerangkan bahwa meskipun nafkah ditunaikan oleh suaminya berdasarkan kemampuannya, namun tetap saja nafkah tersebut merupakan kewajiban bagi suami kepada istri dan anaknya yang tidak boleh dilalaikan.

Di sisi lain Pasal 80 ayat (6) menjelaskan bahwa sebagai istri dapat membaskan suaminya dari kewajiban dalam pemenuhan atas nafkah, tempat tinggal, dan biaya rumah tangga serta biaya perawatan atau pengobatan istri dan anak. Ini menunjukan bahwa seorang istri berhak untuk membebaskan atas suaminya dari kewajiban dalam pemenuhan nafkah kepadanya, kendati demikian meskipun istri tidak menggunakan hak tersebut maka suami tetap memiliki kewajiban untuk memenuhi nafkah yang harus ditunaikan kepada istrinya.

Sebagai seorang suami memiliki kewajiban untuk Nafkah Madhiyah yakni nafkah lampau atau nafkah terdahulu yang menjadi kewajiban suami terhadap istrinya ketika dalam ikatan perkawinan. Nafkah ini belum ditunaikan oleh suami dalam kurun waktu tiga bulan atau lebih dan dapat dijadikan sebagai nafkah terutang. Nuriel Amiriyyah menjelaskan bahwa Nafkah Madhiyah sebagai nafkah yang belum dipenuhi oleh seorang suami selaku kepala rumah tangga terhadap

15 Khairuddin, Badri, and Nurul Auliyana, "Pertimbangan Hakim Terhadap Putusan Nafkah Pasca Perceraian (Analisis Putusan Mahkamah Syar'iyah Aceh Nomor 01/Pdt.G/2019/Ms.Aceh)," Journal of Chemical Information and Modeling 53, no. 9 (2019): hlm. 171.

16 Khairuddin, Badri, and Auliyana, hlm. 171. 
istrinya. ${ }^{17}$ Maka dari itu, istri memiliki hak untuk mengajukan gugatan terhadap suaminya kepada Pengadilan Agama dengan gugatan nafkah madbijah atau nafkah yang belum dituntaskan oleh suami selama lebih dari tiga bulan berturut-turut sesuai yang tercantum dalam Shigat Thalaq. Kendati demikian, tidak dijelaskan secara eksplisit dalam KHI perihal diperbolehkan atau tidaknya menuntut nafkah lampau yang sengaja dilalaikan. Namun, penulis berpendapat bahwa nafkah anak maupun pemeliharaan anak (badhanab) dibebankan kepada ayah dan menjadi tanggungjawabnya.

Nafkah anak tersebut diberikan sesuai kadar kemampuan dengan jangka waktu sampai anak berusia dewasa atau mencapai usia 21 tahun ketika sudah mampu mengurus diri atau anak sudah mampu menikah, sehingga dalam situasi seorang anak yang masih membutuhkan biaya penghidpan dari orangtua khususnya ayah, maka ayah tidak boleh melalaikan tanggungjawabnya dengan sengaja. Hal itu telah diatur dalam Pasal 156 huruf (d) KHI bahwa "semua biaya badhanah dan nafkah anak menjadi tanggung jawab ayah menurut kemampuannya, sekurang-kurangnya sampai anak tersebut dewasa dapat mengurus diri sendiri (21 tahun)"

Nafkah iddah juga merupakan nafkah yang diberikan bekas suami setelah terjadinya perceraian. Maksud nafkah iddah atau nafkah cerai ialah tunjngan yang diberikan seorang pria kepada mantan istrinya sesuai dengan putusan pengadilan yang menyelesaikan perceraian mereka. Dalam Al-Qur'an dan Hadis maupun hukum positif, tidak ada ketentuan yang mengatur terkait kadar pemberian nafkah iddah yang diberikan.

Adapun nafkah mut'ah sebagai nafkah penghibur, artinya bahwa nafkah yang diberikan sesuai kemampuan. Mut'ah juga dapat diartikan sebagai sesuatu yang apabila mendapatkannya dapat diperoleh beberapa manfaat atau kesenangan. Berdasarkan hal tersebut, dapat disimpulkan bahwa pemberian mut'ab seorang suami terhadap istri yang diceraikan bertujuan untuk menghibur atau menyenangkan hati mantan istri dan diharapkan dapat menjadi bekal hidup, membersihkan hati kaum wanita serta menghilangkan kekhawatiran penghinaan kaum pria terhadapnya.

Di samping peraturan perundang-undangan berkenaan dengan nafkah yang telah diatur dalam Inpres No. 1 Tahun 1991 tentang Kompilasi Hukum Islam serta ditegaskan pula pada UU No. 1 Tahun 1974 tentang Perkawinan, dijelaskan pula dalam Surat Edaran Mahkamah Agung Nomor 3 Tahun 2018 Hasil Pleno Agama pada point 2 yang menyebutkan bahwa: "Nafkah madhiyah, nafkah, iddah, mut'ah, dan nafkah anak menyempurnakan rumusan Kamar Agama dalam SEMA No. 7 Tahun 2012 angka 16 sehingga berbunyi: "Hakim dalam menetapkan nafkah madbiyah, nafkah iddah, nafkah mut'ah, dan nafkah anak, harus mempertimbangkan

17 Amiriyyah Nuriel, "Nafkah Madliyah Anak Pasca Perceraian: Studi Putusan Mahkamah Agung Republik Indonesia Nomor 608/K/AG/2003" 6 No. 1, no. 1 (2015): hlm. 1, https://doi.org/https://doi.org/10.18860/j.v6i1.4085. 
rasa keadilan dan kepatutan dengan menggali fakta kemampuan ekonomi suami dan fakta kebutuhan dasar hidup isteri dan/atau anak".

Dalam rangka mengimplementasikan bunyi point 3 dari SEMA No. 03 Tahun 2018 Hasil Pleno Kamar Agama yang dijelaskan bahwa: "isteri dalam perkara cerai gugat dapat diberikan nafkah madhiyah, nafkah, iddah, mut'ah, dan nafkah anak sepanjang tidak nusyuz". Maka dari itu berdasarkan Perma tersebut, khusus pada perkara cerai gugat tidak menutup kemungkinan pihak Penggugat atau yang dalam hal ini adalah istri memiliki hak untuk mengajukan tuntutan atas nafkah madhijah, iddah, mut'ah, dan nafkah anak sepanjang istri tidak bersikap nusyuz.

Perlu diperhatikan pula bahwa dalam perkara cerai gugat dimungkinkan pula untuk diajukan tuntutan nafkah, namun dalam ini Majelis Hakim harus benar-benar secara seksama dalam menggali peristiwa dan menemukan fakta hukum yang akan dijadikan sebagai dasar dikabulkan atau tidaknya tuntutan nafkah tersebut.

Berbeda dengan perkara cerai talak pada Pasal 8 angka (3) huruf (c) PERMA No. 3 tahun 2017 tentang Pedoman Mengadili Perkara Perempuan Berhadapan dengan Hukum, "(3) Dalam hal pemulihan korban atau pihak yang dirugikan hakim agar: (c) mempertimbangkan situasi dan kepentingan korban dari kerugian yang tidak proporsional akibat ketidak setaraan Gender. Dengan demikian Majelis Hakim menetapkan agar uang mut'ah dan uang nafkah $i d d a h$ di bayarkan bersamaan dengan ikrar talak di ucapkan oleh Pemohon yang mana pihak Pemohon tidak dapat menjatuhkan ikrar talaknya apabila belum memenuhi yang menjadi kewajibannya sebagai mana dalam amar putusan.

Adanya pembayaran nafkah iddah dan mut'ah yang dilaksanakan sebelum ikrar talak ini didasarkan pada Perma No. 3 Tahun 2017 dalam angka 1 yang berbunyi: "Dalam rangka pelaksanaan Perma No.3 Tahun 2017 tentang pedoman mengadili perkara perempuan berhadapan dengan hokum untuk memberikan perlindungan hukum bagi hak-hak perempuan pasca perceraian, maka pembayaran kewajiban akibat perceraian, khususnya nafkah iddah, mut'ah, madhiyah, dapat dicantumkan dalam amar putusan dengan kalimat dibayar sebelum pengucapan ikrar talak. Ikrar talak dapat dilaksanakan bila istri tidak keberatan atas suami tidak membayar kewajiban tersebut pada saat itu".

SEMA No. 3 Tahun 2018 berkaitan dengan bunyi isi Pasal 149 huruf b KHI: Bilamana perkawinan putus karena cerai talak maka bekas suami wajib: b. Memberi nafkah, maskan, dan kiswah kepada bekas istri selama dalam iddah, kecuali bekas istri telah dijatuhi talak ba'in atau nusyur dan dalam keadaan tidak hamil. Sedangkan dasar hukum lainnya berkenaan dengan nafkah diantaranya dimuat pada Pasal 80 ayat $2 \mathrm{KHI}$ yang bunyinya: Suami wajib melindungi Istrinya dan memberikan segala sesuatu keperluan hidup berumah tangga sesuai dengan kemampuannya.

Aden Rosadi menjelaskan bahwa pemberian nafkah mut'ab suami kepada mantan istrinya mesti dilakukan melalui penetapan Pengadilan Agama setempat, baik yang berhubungan dengan perkara cerai talak maupun cerai gugat. Disamping itu, pemberian nafkah mut'ah sesungguhnya lebih berimplikasi pada keber- 
langsungan melakukan kewajiban untuk menjaga, memelihara, dan menafkahi anak keturuan. Sebab, anak sampai kapan pun tidak mengenal istilah mantan ayah atau ibu. Sedangkan suami dan istri, mengenal istilah mantan suami dan mantan istri. ${ }^{18}$

\section{Pertimbangan Majelis Hakim dalam Menentukan Kadar Besaran Nafkah}

Dalam memberikan pertimbangan terhadap penentuan nafkah, majelis hakim didasarkan kepada dua ha ${ }^{19}$ pertama ketika istri tidak termasuk dalam kategori nusyu $2^{20}$ dan kedua berdasarkan penghasilan suami (fektor ekonomi). Dua kategori tersebut menjadi bahan pertimbangan ketika tidak menemukan kesepakatan antara kedua belah pihak, baik berdasarkan keinginan dari istri ataupun suami yang tidak mau untuk memenuhi permtintaan dari pihak istri.

Pertimbangan selanjutnya oleh hakim setelah diketahui penghasilan suami maka hakim akan memberikan pertimbangan dalam hal kebutuhan masingmasing pihak. Kebutuhan tersebut ialah kebutuhan yang wajar dari biaya penghidupan sehari-hari berupa makanan, biaya hidup lainnya dalam jangka waktu tertentu dan atau tempat tinggal bagi bekas istri selama menjalani masa idahnya.

Seorang bekas suami diwajibkan untuk memberikan nafkah, namun kewajiban tersebut dilaksanakan apabila terbukti nafkah tersebut tidak ditunaikan dengan baik oleh suami ketika masih dalam ikatan perkawinan, sedangkan keadaan suami mengetahui betul bahwa memenuhi nafkah merupakan salah satu kewajiban dalam pernikahan. Disamping itu, dalam keadaan suami mengetahui hakim telah menentukan besaran nafkah yang wajib harus dibayar, namun suami tetap sengaja tidak membayarkan nafkah, maka hakim berhak untuk menjual harta yang dimikili suami secara paksa dan kemudian membayarkan hasil penjualan atas harta tersebut untuk dibayarkan kepada istrinya sebagai nafkah yang terutang sesuai kebutuhan istrinya. Akan tetapi, lain halnya jika ternyata suami memang tidak mempunyai harta sehingga tidak mampu untuk membayarkan nafkah, maka ia tidak boleh dipaksa oleh hakim untuk membayar nafkah, istri wajib menunggu sampai suaminya tersebut berkelapangan.

Kebutuhan seorang suami dalam penentuan besaran nafkah terhadap mantan istrinya menjadi salah satu pertimbangan, karena dikhawatirkan jika sautu putusan hakim yang telah ditetapkan oleh hakim dalam jumlah yang banyak, dan ternyata mantan suami untuk keperluan sendirinyapun tidak dapat terpenuhi, maka putusan hakim tersebut menjadi tidak adil bagi pihak mantan suami. Dalam hal ini hakim harus juga bisa menentukan jumlah nafkah yang ditentukan berdasarkan

18 Aden Rosadi, Peradilan Agama Di Indonesia Dinamika Pembentukan Hukum (Bandung: Simbiosa Rakatama Media, 2015).

19 Khairuddin, Badri, and Auliyana, "Pertimbangan Hakim Terhadap Putusan Nafkah Pasca Perceraian (Analisis Putusan Mahkamah Syar'iyah Aceh Nomor 01/Pdt.G/2019/Ms.Aceh)," hlm. 182.

20 Ahmad Azhar Basyir, Hukum Perkawinan Islam (Yogyakarta: UII Press, 2007), hlm. 88. 
penghasilan dari mantan suami yang dikurangi dengan kebutuhan dari pihak masing-masing, selan itu pula diharapkan dari ditetapkannya putusan tersebut dapat dilaksanakan tanpa merugikan kedua belah pihak. ${ }^{21}$

Andi Syamsu Alam salah satu Hakim Mahkamah Agung memberikan penjelasan bahwa walaupun oleh undang-undang diperbolehkan, gugatan nafkah masih belum popular atau dikenal oleh di masyarakat. masih banyak yang tidak mengetahui bahwa gugatan nafkah bisa diajukan, bahkan apabila anak butuh biaya sekolah namun bapaknya yang mampu ternyata tidak mau memberikan biaya kepada anaknya, maka hal ini bisa digugat". ${ }^{22}$ Terhadap nafkah anak, bagi seorang ayah tidak boleh melalaikan tanggungjawab dan kewajibannya dalam memberikan nafkah terhadap anaknya, sekalipun ayah dan ibu dari anak tersebut telah bercerai. Peraturan sebagaimana termaktub dalam Kompilasi Hukum Islam menjelaskan bahwa pemberian nafkah disesuaikan dengan kemampuan ayah.

Ada beberapa faktor yang menjadi pertimbangan majelis hakim dalam menentukan kadar besaran nafkah yang harus diberikan oleh bekas suami setelah perceraian terhadap istri dan anak-anaknya: a) berdasarkan kepatutan dan kemampuan suami yang diukur dengan melihat penghasilan suami setiap bulannya, b) melihat usia perkawinan yang telah dijalankan, c) melihat apakah istrinya nusyuz atau tidak, d) menyesuaikan antara kebutuhan dan kemampuan suami sesuai dengan kondisi suatu daerah, e) melihat apakah seorang suami melakukan kedzaliman terhadap istrinya, seperti kekerasan dalam rumah tangga. Dari beberapa faktor tersebut menjadi dasar pertimbangan majelis hakim dalam mengambil keputusan terhadap penetapan jumlah nafkah dan setelah perceraian yang harus diberikan seorang mantan suami kepada istri dan anak-anaknya.

\section{Kesimpulan}

Persoalan berkaitan dengan nafkah sampai saat ini memang masih belum populer di kalangan masyarakat umum. Namun ada beberapa dasar hukum tentang gugatan nafkah, diantaranya mengacu kepada SEMA No. 3 Tahun 2018 Hasil Pleno Kamar Agama pada point 2 yang menyempurnakan rumusan Kamar Agama dalam SEMA No. 7 Tahun 2012 angka 16. Disamping itu, dalam perkara cerai gugat pihak istri memiliki hak untuk mendapatkan nafkah madbiyah, nafkah iddah, nafkah mut'ah serta nafkah anak dengan syarat istri tidak melakukan perbuatan nusyu₹. Hal tersebut selaras dengan bunyi SEMA No. 03 Tahun 2018 Point 3. Berbeda dengan perkara cerai talak pada Pasal 8 angka (3)

21 Kalsum, "Pertimbangan Hakim Terhadap Nafkah Istri Dalam Kasus Cerai Talak Di Pengadilan Agama Watampone Kelas 1 A," hlm. 259.

22 Diana Kusumasari, "Bisakah Menuntut Ayah Karena Tidak Memberi Nafkah?," hukumonline.com, 2011, diakses pada tanggal 23 Februari 2021, pukul 15.30 WIB. https://www.hukumonline.com/klinik/detail/ulasan/lt4dff1ad6cc74e/bisakah-menuntutayah-karena-tidak-memberi-nafkah-/. 
huruf (c) PERMA No. 3 tahun 2017 tentang Pedoman Mengadili Perkara Perempuan Berhadapan dengan Hukum, "(3) Dalam hal pemulihan korban atau pihak yang dirugikan hakim agar: (c) mempertimbangkan situasi dan kepentingan korban dari kerugian yang tidak proporsional akibat ketidak setaraan Gender. Dengan demikian Majelis Hakim menetapkan agar uang mut'ah dan uang nafkah iddah di bayarkan bersamaan dengan ikrar talak di ucapkan oleh Pemohon yang mana pihak Pemohon tidak dapat menjatuhkan ikrar talaknya apabila belum memenuhi yang menjadi kewajibannya sebagai mana dalam amar putusan. Pertimbangan majelis hakim dalam penentuan kadar besaran nafkah madbiyah, nafkah iddah, mut'ah serta nafkah anak ukurannya dapat disesuaikan dengan kemampuan suami, istri tidak melakukan perbuatan nusyur, dan disesuaikan dengan kebutuhan yang wajar dari masing-masing pihak.

\section{Daftar Pustaka}

Arnengsih, A, and Mohamad Sar'an. "Hak Asuh Anak Akibat Cerai Gugat Dalam Perkara Nomor 0915/Pdft.G/2017/PA.Bgr." Al-Ahwal Al-Syakhsiyyah: Jurnal Hukum Keluarga Dan Peradilan Islam 1, no. 2 (2020): 123-34. https://doi.org/10.15575/as.v1i2.9910.

Basyir, Ahmad Azhar. Hukum Perkawinan Islam. Yogyakarta: UII Press, 2007.

Bisri, Cik Hasan. Peradilan Islam Dalam Tatanan Masyarakat Indonesia. Bandung: Rosdakarya, 1997.

Fakhria, Sheila. "Cerai Gugat Dan Implikasinya Terhadap Hak-Hak Finansial Perempuan." Legitima: Jurnal Hukum Keluarga Islam 1, no. 1 (2019): 91-119. https://doi.org/10.33367/legitima.v1i1.648.

Fatmawati, Fatmawati. "Kewenangan Peradilan Agama Dalam Memutus Perkara Perceraian Akibat Murtad." Jurnal Ilmiah Pendidikan Pancasila Dan Kewarganegaraan 2, no. 1 (2017): 26-33. https://doi.org/10.17977/um019v2i12017p026.

Ihwanudin, Nandang. "Pemenuhan Kewajiban Pasca Perceraian Di Pengadilan Agama." ADLIY A: Jurnal Hukum Dan Kemanusiaan 10, no. 1 (2019): 51-68. https://doi.org/10.15575/adliya.v10i1.5146.

Jannah, Hasanatul. "Kompetensi Hukum Pemenuhan Nafkah Istri Pasca Perceraian." De Jure, Jurnal Syariah Dan Hukum 2, no. 1 (2010): 71-79. https://doi.org/https://doi.org/10.18860/j-fsh.v2i1.57.

Jundan, Gozwan. "Perceraian Usia Tiga Tahun Perkawinan Dari Pasangan Muda." Al-Ahwal Al-Syakhsiyyah: Jurnal Hukum Keluarga Dan Peradilan Islam 1, no. 1 (2020): 39-60. https://doi.org/10.15575/as.v1i1.7801.

Kalsum, Ummu. "Pertimbangan Hakim Terhadap Nafkah Istri Dalam Kasus Cerai 
Talak Di Pengadilan Agama Watampone Kelas 1 A." Jurisprudentie: Jurusan Ilmu Hukum Fakultas Syariah Dan Hukum 6, no. 2 (2019): 57. https://doi.org/10.24252/jurisprudentie.v6i2.9766.

Khairuddin, Badri, and Nurul Auliyana. "Pertimbangan Hakim Terhadap Putusan Nafkah Pasca Perceraian (Analisis Putusan Mahkamah Syar'iyah Aceh Nomor 01/Pdt.G/2019/Ms.Aceh)." Journal of Chemical Information and Modeling 53, no. 9 (2019): 1689-99.

Kusumasari, Diana. "Bisakah Menuntut Ayah Karena Tidak Memberi Nafkah?" HukumOnline.com, 2011. https://www.hukumonline.com/klinik/detail/ulasan/lt4dff1ad6cc74e/bisak ah-menuntut-ayah-karena-tidak-memberi-nafkah-/.

Mukhlas, Oyo Sunaryo. Perkembangan Peradilan Islam. Bandung: Ghalia Indonesia, 2011.

Muthi'ah, Aulia. Hukum Islam Dinamika Seputar Hukum Keluarga. Yogjakarta: Pustaka Baru, 2017.

Nelli, Jumni. "Analisis Tentang Kewajiban Nafkah Keluarga Dalam Pemberlakuan Harta Bersama." Al-Istinbath: Jurnal Hukum Islam 2, no. 1 (2017): 29. https://doi.org/10.29240/jhi.v2i1.195.

Nuriel, Amiriyyah. "Nafkah Madliyah Anak Pasca Perceraian: Studi Putusan Mahkamah Agung Republik Indonesia Nomor 608/K/AG/2003" 6 No. 1, no. 1 (2015): 1-15. https://doi.org/https://doi.org/10.18860/j.v6i1.4085.

Rasjid, H. Sulaiman. Figh Sunnah. Bandung: Sinar Baru Algesindo, 1994.

Rosadi, Aden. Peradilan Agama Di Indonesia Dinamika Pembentukan Hukum. Bandung: Simbiosa Rakatama Media, 2015.

Sururie, Ramdani Wahyu, and Harry Yuniardi. "Perceraian Dalam Keluarga Muslim Di Jawa Barat." Jurnal Al-Manabij XII, no. 2 (2018): 263-80. https://doi.org/https://doi.org/10.24090/mnh.v12i2.1361. 